\title{
nature
}

\section{No hemlock in future harvest}

\section{The US National Academy of Sciences has missed a trick in failing to make its white paper on genetic manipulation into an effective attack on present bumbledom.}

THE US National Academy of Sciences has done a valuable public service by deciding to speak some simple common sense about the release of genetically-engineered organisms to the environment. Whether it will be much thanked for having done so is another matter. For what an academy committee under Dr Arthur Kelman, the Wisconsin botanist, has said is that enough is now known about the nature of genetically engineered organisms, and about the relationship between them and other kinds of artificial varieties (animal as well as plants), for the consequences of what is called controlled release to be predictable. There are many other than Mr Jeremy Rifkin, the activist, to whom this conclusion will be unpalatable. Those whose profession is the maintenance of regulations, and even their elaboration, will naturally be downcast. It is more worrying that there persists, in spite of fifteen years of restraint on research (some of it voluntary), a general unease outside the technical community at the potential, if not the practice, of genetic manipulation. How well will the academy's committee have put that to rest?

By the academy's idiom, the occasion is important. Like most other learned societies, the US academy does not easily arrive at collective opinions on matters of general importance. Although a prolific publisher of pronouncements on matters as different as containing the spread of AIDS and the problems of engineering education, these opinions are not put out as collective views, although great attention is paid to the basis on which the arguments are founded and the logic by which the academy arrives at its conclusions. The Kelman document was intended to be a little more than the standard publications, a policy statement ranking with what governments call white papers. What will happen to it now that it has been leaked to the New York Times at the weekend is anybody's guess.

\section{Survival}

The Kelman report nevertheless says all the right things. The observation that all possible organisms are likely already to have had at least a fleeting existence in the course of evolution is not a valid defence of the release of anything and everything to the environment; for one thing, the assertion is probably incorrect, but randomly generated organisms are unlikely to have occurred in circumstances that favour their survival. On the other hand, "accumulated experience in plant and animal breeding" of the conventional kind shows that artificially bred organisms are at a disadvantage in the 'wild', suggesting that artificially engineered organisms are competitively disadvantageous. If anything, genetic manipulation of the DNA of an organism will be safer than conventional breeding because of its precision - unwanted genes with unpredictable effects are not, for example, carried along - so that the 'new' organisms that people wish to introduce into the environment are strictly analogous to the varieties and cultivars that the conventional breeders introduce (and for which they are now able to secure breeders' rights).

The weakness of the document is that it continues in this vein of generality. What of the chance that genetically engineered crop plants will turn out also to be superior weeds, as in H.G.Wells's splendid Food of the Gods? The Kelman report correctly observes that for a plant to be successful as a weed, it requires several of a considerable constellation of genetic attributes with which it is unlikely to be endowed by deliberate manipulation in the laboratory. The committee is right to say that plant breeders using the new techniques will have no incentive to provide their creations with mechanisms for the wide dispersal of their seed or with the means of making sure that seeds remain viable for long periods and germinate quickly when the environment is favourable, or any other of the mechanisms by which plants spread without financial advantage to their creators. But this will not satisfy the protesters, who will remark that circumstances may be very different when laboratories all over the world are practising these techniques. And what, they will ask, will ensure that malevolent experiments are not mounted, perhaps by military agencies who find it convenient to consider that the existing conventions prohibiting biological warfare do not interdict warfare against other people's crops?

\section{Havoc}

The academy's white paper is on more politic ground when it argues the need that those who plan experiments and succeeding commercial developments should at the outset give careful consideration to the biological characteristics of their organisms and the nature of the environment into which they will be introduced. After all, there is now a considerable catalogue of occasions on which the deliberate introduction of exotic but naturally occurring species into natural habitats has caused havoc. The committee is right to distinguish between engineered plants used in the artificial and reasonably well-understood conditions of modern farming, where it is even possible to engineer methods of control, and the introduction of engineered species into natural environments whose complexity may not yet be unravelled. So, the Kelman committee says, "the scientific community urgently needs to provide guidelines to both investigators and regulators in evaluating planned introductions of modified organisms from an ecological perspective". That would be handy. But is not the danger that the regulators will be the providers, and that the scientific community will have to live within the guidelines, no matter how unpalatable or nonsensical?

That is why it would have been an even greater public service if the academy's white paper had dealt directly with the regulatory issues that now unreasonably impede research and development in the genetic manipulation of plants (where quarantine is often mechanically impossible). It is of course ridiculous (as the committee says with more gentility) that artificially bred varieties should be dealt with differently according to the manner in which they are produced, but equally there is every chance that public confidence in the potential boon of DNA manipulation will be the more quickly established if the likely effects of introducing novel varieties are deliberately assessed in advance, not merely by the manipulators but by some detached body of invigilators. The intolerable feature of present arrangements in the United States is the opportunity, apparently endless, for unreasoned dissent to obstruct benign development. It is no wonder, if nothing to be proud about, that some investigators from time to time kick over the traces (see page 659). 